\title{
THE SUPREME COURT AND THE DIVISION OF POWERS: COMMENTARY
}

\author{
THE HONOURABLE LOUIS-PHILIPPE PIGEON, \\ JUSTICE OF THE SUPREME COURT OF CANADA
}

Je me permettrai de commencer ces observations par un rappel de souvenirs. J'étais étudiant en première année de Droit lorsque le Conseil Privé jugea l'affaire Nadan [1926] A.C. 482. Chacun sait que le Conseil Privé y décida que le Parlement fédéral était empêché par le Colonial Laws Validity Act d'abolir la prérogative de cet auguste tribunal de se saisir de toute affaire ou il pouvait juger à propos d'accorder une autorisation spéciale. Ce que l'on sait moins c'est qu'avant d'en venir à cette conclusion-là, il a dit (pp. 489-490):

An attempt was made to distinguish the appeal against the conviction under the Government Liquor Control Act of Alberta from the appeal against the conviction under the Canada Temperance Act on the ground that the penalties under the former statute are imposed by a Provincial statute which does not incorporate s.1025 of the Criminal Code; but this contention appears to their Lordships to be negatived by the judgment of the Board in Rex v. Nat Bell Liquors [1922] 2 A.C. 128 at 167. Sect. 1025 is expressed to apply to an appeal in a criminal case from "any judgment or order of any Court in Canada," and this expression is wide enough to cover a conviction in any Canadian Court for breach of a statute, whether passed by the Legislature of the Dominion or by the Legislature of the Province.

Le Conseil Privé se trouva donc à décider ainsi que le Parlement fédéral avait valablement, par une loi remontant à 1887 (50-51 Vict., c.50), enlevé aux cours provinciales le pouvoir d'accorder l'autorisation d'appeler au Conseil Privé. En effet, dans Nadan, la Cour d'appel de l'Alberta avait donné cette autorisation non seulement pour des infractions à la loi fédérale, mais aussi pour des infractions à la loi provinciale sur les boissons alcooliques. Il était donc, d’ores et déjà décidé que, si l'on faisait disparaître le Colonial Laws Validity Act, le Parlement fédéral aurait ipso facto le pouvoir d'abolir les appels au Conseil Privé en toutes matières fédérales et provinciales.

Quelques mois plus tard, il fut convenu à une conférence impériale d'accorder au Canada et aux autres possessions britanniques alors appelées "Dominions", la souveraineté extérieure. Cela impliquait naturellement le rappel du Colonial Laws Validity Act et la suppression de la vieille interdiction de légiférer à l'encontre des lois de ce que l'on appelait le "Parlement impérial". Quand, après quelques années, on rédigea à Londres le projet de la loi destinée à donner suite aux décisions de la conférence dans le domaine législatif, le Gouvernement canadien se voyait déjà maître de la constitution du pays. Les gouvernements provinciaux ne voyaient pas l'affaire du même oeil. Finalement, le résultat d'une conférence célèbre fut qu'on se mit d'accord sur ce qui devint l'art. 7 du statut de Westminster.

Quelques mois après l'adoption définitive de la loi, Me Aimé Geoffrion qui avait été l'un des aviseurs à la conférence, vint donner une causerie sur le sujet à la Société des Etudes juridiques de Québec. Au cours de la discussion qui suivit, je lui posai la question suivante: "Est-ce que le statut comme on l'a voté n'a pas pour effet de donner au Parlement fédéral le pouvoir d'abolir les appels au Conseil Privé?" Réponse: "On n’y a pas pensé."

En 1940, le juge en chef Duff devait dire: (1940 R.C.S. 49, à 59):

I think we are bound by the judgment of the Judicial Committee in Nadan v. The King [1926] A.C. 482 as interpreted by the British Coal Corporation v. The King [1935] A.C. 500 , to hold that legislation intended to prevent the exercise of the prerogative in relation to the judgments of Canadian courts is not legislation in relation to a local matter in that sense. 
Petit détail à noter en marge des observations du professeur Bonenfant sur l'attitude du Québec envers la Lour suprême du Canada: le même premier ministre québecois qui n'envoya pas de procureur à l'audition devant elle en juin 1939, fit produire une intervention au Conseil Privé en 1947 (1947 A.C. 127).

Le professeur Bonenfant a noté que je n'aime guère qu'on me cite. C'est exact, lorsque je suis sur le banc. Mais, dans le domaine académique, il en est autrement. Aujourd'hui je me permettrai même de me citer, ce que je ne fais jamais à la Cour. En guise de commentaire sur les conclusions du professeur Cairns citées par le professeur Lederman, je relirai la conclusion de mon article "The Meaning of Provincial Autonomy" (29 Can. Bar Rev. 1126, à 1135) écrit en 1951, c'est-à-dire au moment où le Conseil Privé mettait le point final à sa jurisprudence sur la constitution canadienne:

A great volume of criticism has been heaped upon the Privy Council and the Supreme Court on the ground that their decisions rest on a narrow and technical construction of the B.N.A. Act. This contention is ill-founded. The decisions on the whole proceed from a much higher view. As appears from passages I have quoted, they recognize the implicit fluidity of any constitution by allowing for emergencies and by resting distinctions on questions of degree. At the same time they firmly uphold the fundamental principle of provincial autonomy: they staunchly refuse to let our federal constitution be changed gradually, by one device or another, to a legislative union. In doing so they are preserving the essential condition of the Canadian confederation.

Everyone will appreciate that it is not easy for me to comment on the evolution of Canadian constitutional law subsequent to the abolition of Privy Council appeals. I will therefore make no observations concerning Professor Lederman's comments on Professor Weiler's views. I will however read to you, without comment, this excerpt from a CBC broadcast of April 81975 , taken from my own taping of that program celebrating the 100th anniversary of the sanctioning of the initial Supreme Court Act:

(Paul Weiler) If the Supreme Court of Canada decides something like one hundred and fifty cases a year in the twenty-five years or so since they've become a final Court twenty-five times a hundred to a hundred and fifty and it's the incremental growth of the law over all of that period of time that makes Canadian law now just totally different from what it looked like in 1949 when the Supreme Court of Canada became the final Court of appeal, and the number there is, the most obvious and maybe the most important instance of that, is in the constitutional area. What happened with the Privy Council from some time around World War I through to the end of World War II was that there were a number of decisions which said that the legislatures, both the federal government and the provincial government, could not do certain things. Mr. Justice Laskin, who was then a professor, said that the Privy Council imposed a constitutional strait jacket on Canadian Government. Now, in twenty-five years of decisions, and you cannot point to any particular case as a dramatic event, but over this period of twenty-five years of decisions, the Supreme Court of Canada gradually removed that strait jacket.

Everyone of you knows, I am sure, that I believe in literal interpretation. This is my concept of abiding by the will of Parliament. However, I have to accept that this is impossible in constitutional adjudication and in the implementation of the Bill of Rights. Tests of constitutional validity cannot be rigidly devised. The decision in those matters has to rest on broad principles, not on technical construction. As I see it, the U.S. Supreme Court in effect allowed Congress to set the limits of federal legislative power in most matters when it said: "The federal commerce power is as broad as the economic needs of the nation" (per Murphy J. in American Power and Light Co. v. S.E.C. (1946) 67 S.Ct. 133).

The contrast between the attitudes of the U.S. Court and the Supreme Court of Canada concerning the Bill of Rights is even more striking and is best illustrated, I think, by recent decisions on abortion. Where the U.S. Court saw 
fit to assume legislative authority, this Court unanimously refused to interfere with the substantive content of the legislation. Let me quote this paragraph from the Chief Justice's reasons:

This Court indicated in the Curr case how foreign to our constitutional traditions, to our constitutional law and to our conceptions of judicial review was any interferenco by a court with the substantive content of legislation. No doubt, substantive content had to be measured on an issue of ultra vires even prior to the enactment of the Canadian Bill of Rights, and necessary interpretative considerations also had and have a bearing on substantive terms. Of course, the Canadian Bill of Rights introduced a new dimension in respect of the operation and application of federal law, as the judgments of this Court have attested. Yet it cannot be forgotten that it is a statutory instrument, illustrative of Parliament's primacy within the limits of its assigned legislative authority, and this is a relevant consideration in determining how far the language of the Canadian Bill of Rights should be taken in assessing the quality of federal enactments which are challenged under s.1(a). There is as much temptation here as there is on the question of ultra vires to consider the wisdom of the legislation, and I think it is our duty to resist it in the former connection as in the latter.

To close these observations, I will read another excerpt from the April 8 broadcast, the speaker this time being professor Harry Arthurs:

They are a conservative group of people and these aren't always in controversial areas such as civil liberties, constitutional arrangements, the same is true in tort law, the same is true in administrative law, it's true in labour law, it's true in almost any field of law, the Court hasn't been at the forefront nor I think necessarily should have been. I think that for many of those kinds of matters it's right and proper that the people speaking through their elected representatives should decide what public policy ought to be, and it is a bit of a snare and delusion and a lot of people fall into it and say the Court should give leadership. The fact of the matter is that the Court that leads in the direction they want to go could as easily lead them in the opposite direction. I think the real issue is whether the Court has a mandate or ought to have a mandate to go off leading the parade, or whether if we're to reform tort law it should be because we decide as a public matter that certain kinds of wrongs should be compensated, if we want to reform labour law shouldn't it be for the legislature to grasp the mettle and decide what activity is or isn't permitted during a strike, what's the scope of the Labour Board's authority whatever it might be. 